\title{
GRADE OF ESOPHAGEAL CANCER AND NUTRITIONAL STATUS IMPACT ON POSTSURGERY OUTCOMES
}

\author{
Flávia Andréia MARIN1, Vânia Cristina LAMÔNICA-GARCIA², \\ Maria Aparecida Coelho de Arruda HENRY ${ }^{3}$ and Roberto Carlos BURINI ${ }^{4}$
}

\begin{abstract}
Context - Undernutrition is a well known underlying cause in both disease onset and outcome. Objective - To associate disease severity with pre surgical nutritional status, the main postsurgical complications, and mortality in esophagus cancer patients. Method - Retrospective data from 100 patients (38-81 years old, $85 \%$ males) who had undergone esophagectomy $(\mathrm{G} 1 / \mathrm{n}=25)$ or gastro/jejunostomy $(\mathrm{G} 2 / \mathrm{n}=75)$ between 1995 and 2004. Data included clinical, endoscopic, histological (TNM-UICC), dietary, anthropometric, blood chemistry, and postsurgical ( $>30$ days) complications and mortality. Surgical groups were compared by Student's test and existing associations between variables by either $\mathrm{c}^{2}$ or Fisher exact tests with $P=0.05$. Results - The studied sample was predominantly male $(85 \%)$, white $(80 \%)$, smokers and alcoholics $(95 \%)$, dysphagics $(95 \%)$ mostly presenting body weight loss before cancer diagnosis $(78 \%)$. TNM III and IV predominated over I and II, associated $(P \leq 0.005)$ with higher body mass index and hypoalbuminemia $(<3.5 \mathrm{mg} / \mathrm{dL})$ frequency. Esophagic obstructions $(\mathrm{n}=77)$ were associated $(P=0.002)$ with lower body mass index $\left(\mathrm{kg} / \mathrm{m}^{2}\right)$. Postsurgical complications were more common in G1 $(69.2 \%)$ than G2, predominantly with infections in G2 $(80 \%)$ and pleura-pulmonary in G1 (61\%). Body mass index and lower lymphocyte counts were associated with early infections and postsurgical complications in G2. Plasma albumin levels were lower in this group than G1, and were associated with postsurgical complications and mortality whereas lower lymphocyte counts was associated with mortality in G1. Conclusions - Disease severity (or late diagnosis) is associated with poor nutritional status and palliative surgery which lead to more complicated postsurgery outcome and mortality. Early diagnosis and nutritional intervention are the recommended actions.
\end{abstract}

HEADINGS - Esophageal neoplasms. Neoplasm staging. Nutritional status. Postoperative complications. Fatal outcome.

\section{INTRODUCTION}

By 70 years Scrinshaw et al. ${ }^{(24)}$ described the undernutrition-infection relationship to explain parasitic and infectious outbreaks in third world children. Later, Chandra and $\operatorname{Kumari}^{(6)}$ added immunocompetence creating an undernutrition-immunodeficiency-infection triad which until today explains the appearance and evolution of many pathologies whose proposed solution was to improve the protein-energy state of the host. Moving from the predominance of infectious-contagious diseases in the last century to the non-transmittable chronic diseases of this century, the nutritionimmunocompetence relationship continues. The focus has moved from protein energy shortage to a lack of vitamins, minerals, amino acids, and polyphenols, all lacking in processed foods.

Diet composition and food consumption continue to influence the appearance of cancers. Cancer state and disease severity are modulators of patient nutritional state by affecting food ingestion and nutrient use. Undernutrition itself can modulate disease course. Nutritional care of these and other patients, starts with evaluating nutritional state which establishes the level of compromise for different body compartments and helps indicate the nutritional treatment needed. Surgical aggression causes different levels and complexity of tissue lesions, followed by adaptive reactions which permit the repair of destroyed tissue and activation of immunological defenses, which is a secondary adaptive response to changed surgical trauma in malnourished patients $^{(11)}$

The main postoperative repercussions of undernutrition are metabolic, represented by hypoglycemia and reduced hematocrit, and organic or clinical, such as coagulation and healing problems, respiratory phenomena, and infections $s^{(5,25)}$.

Studies have shown the important relationship between nutritional deficit and complications occurring during surgical treatment of esophagus cancer

\footnotetext{
Approved MSNutr Dissertation in the Basic Surgery Program, Botucatu School of Medicine State University of São Paulo (UNESP), Botucatu, SP, Brazil.

${ }^{1}$ Basic Surgery Program, Botucatu School of Medicine - UNESP; ${ }^{2}$ Graduate of Basic Surgery Program, Botucatu School of Medicine - UNESP; ${ }^{3}$ Department of Surgery and Orthopedics, Botucatu School of Medicine - UNESP; ${ }^{4}$ Public Health Department, Botucatu School of Medicine - UNESP, Botucatu, SP, Brazil.

Correspondence: Prof. Roberto Carlos Burini - Centro de Metabolismo em Exercício e Nutrição (CeMENutri) - Departamento de Saúde Pública, UNESP - Rubião Júnio 18618-970 - Botucatu, SP, Brazil. E-mail: burini@fmb.unesp.br
} 
patients ${ }^{(22)}$. The nutritional state of esophagus cancer patients is often precarious ${ }^{(4)}$, with nutritional implications determined by the inability or difficulty in oral feeding and secondary metabolic alterations due to the presence of the malignance ${ }^{(8)}$.

The nutritional implications of this type of cancer have been related to malignity and linked metabolic abnormalities. Reduced protein-energy ingestion is caused by the local effect of the tumor, mainly esophageal obstruction, dysphagia, pain, odynophagia, and systemic origin anorexia ${ }^{(10)}$.

Curative surgical treatment by radical esophageal resection, aims to remove the whole tumor, in patients without distant metastases or invasion of adjacent structures, having removed all visible tumor with free margins, and lymph node spread. Esophagectomies can be performed by thoracic access (transthoracic route), or transhiatal by abdominal or cervical route ${ }^{(15,21)}$.

Palliative surgical intervention includes performing palliative esophagectomy, ostomy (gastrostomy, jejunostomy) esophageal tunnelization (surgical or endoscopic), gastric or colon transposition (gastroplasty or coloplasty without tumor resection) $)^{(18)}$.

Normal surgical treatment can present acute postoperative problems. Nutritional alterations, due to surgery, are due to the metabolic effects of surgical stress as well as postoperative fasting. Considering complicated postoperative evolution in malnourished patients, nutritional evaluation could be valuable in detecting protein-energy undernutrition (PEU) before surgery making better nutritional intervention possible ${ }^{(1,2,26)}$.

There are few studies identifying nutritional prognosis factors in esophagus cancer patients submitted to surgery which report nutritional indicators with postsurgical complications and hospital death. It is important to establish the association between low cost anthropometric and biochemical nutritional factors, commonly used in clinical practice and patient prognosis. In this sense, the work aimed to study the relationship between nutritional indicators and postoperative morbidity and mortality in esophagus cancer patients.

\section{METHODS}

Medical records were studied of 100 esophagus cancer patients treated by the Gastroenterology Discipline at the Department of Surgery and Orthopedics, Botucatu School of Medicine - UNESP, Botucatu, SP, Brazil, between January 1995 and June 2004.

Patients of both sexes were included with confirmed diagnosis of malignant esophagus neoplasia whom had undergone major surgery (esophagectomy with gastroplasty by transhiatal or transthoracic route) and minor palliative surgery, for alimentary canal construction (gastrostomy and jejunostomy). Patients were divided into two groups: group 1: patients submitted to major surgery $(n=25)$ and group 2: patients submitted to minor surgery $(n=75)$. Tumor staging was made by imaging exams (thorax computed tomography, abdomen ultrasound) and bronchoscopy and International Union Against Cancer TNM classification (UICC, 1987).
Data were distributed in three moments: disease diagnosis or pre surgery, immediately after surgery (up to 30 days after surgery), later after surgery, starting 30 days after surgery and extending until time of death or end of the study.

Pre-operative data from medical records were: gender, age, race, city address, type of surgery, clinical and nutritional history, anthropometric and laboratory evaluations, data from endoscopy exam (type and location), anatomopathological exams, and tumor stage.

Immediate and late postoperative data were pertinent to postoperative evolution, presence and type of adjuvant treatment, and survival.

Data on clinical and nutritional history were: presence and period of dysphagia, diet consistency or fasting, presence of odynophagia, pain, regurgitation, vomiting, cough and hoarseness, hematemesis or melena, alcohol and tobacco consumption, associated diseases and early complications related to esophagus cancer (tracheoesophageal fistula, pneumonia, and septicemia).

Anthropometric data were: height (m) and body weight $(\mathrm{kg})$ with calculation for body mass index (BMI) $\left(\mathrm{kg} / \mathrm{m}^{2}\right)$, weight loss $(\mathrm{kg})$, period of loss which preceded diagnosis. BMI results were classified to World Health Organization reference standards $^{(30,31)}$. Percentage weight loss was calculated using current weight and lost weight in $\mathrm{kg}$; results were classified according to Blackburn et al. ${ }^{(3)}$.

Hematemesis data in medical records (hematocrit, hemoglobin, and total lymphocyte count (TLC)) were classified as per local laboratory norms. TLC was compared to Blackburn et al.(3), and considered acceptable when $>1200 / \mathrm{mm}^{3}$. Plasma albumin and total proteins were classified according to Waitzberg ${ }^{(29)}$, and considered acceptable when $>3.5 \mathrm{~g} / \mathrm{dL}$ and $6.4-8.1 \mathrm{~g} / \mathrm{dL}$, respectively.

Data related to the occurrence of early, immediately postoperative, or later complications were observed and survival was measure in days and later transformed into months.

Postoperative evaluated complications were: pleuropulmonary of infectious or non-infectious origin, cardiovascular, infection at surgery site, septicemia, dehiscence of fistula anastomosis, stenosis, tumor return. Immediately postoperative, emphasis was given to clinical complications related to PEU, such as infections, respiratory complications, and wound healing difficulty.

Statistical analysis compared group means by the Student's $t$ test and associations between variables by analysis of proportions (Chi squared or Fisher exact test) with $P=0.05$.

\section{RESULTS}

The studied sample presented the following demographic characteristics: male predominance $(85 \%)$, white race $(80 \%)$, mean age $58.6 \pm 10.4(38-81)$ years. Smoking and habitual drinking were frequent in $95 \%$ of the sample, with the highest occurrence in those under 60 years $(60 \%)$. Nutritional diagnosis (by BMI) showed that $46 \%$ were eutrophic and $45 \%$ presented PEU. For weight loss, 78\% had lost more than $10 \%$ in the 6 months prior to disease diagnosis. 
The most frequent symptom, reported at time of diagnosis, was dysphagia (95\%) with a mean duration of 4.3 (1-12) months. Most patients had modified their diet consistency from the start and during symptoms, and at moment of disease diagnosis, $83.9 \%$ were on a semi-solid diet, $13.9 \%$ on paste consistency, and $5.7 \%$ on a liquid consistency. Only $2 \%$ had not modified their diet and $17.8 \%$ reported fasting.

The more serious stage (TNM III \& IV) presented higher frequency of ostomiasis, hypoalbuminemia, anemia, lymphopenia, high weight loss, postoperative complications, and low survival (Figure 1).

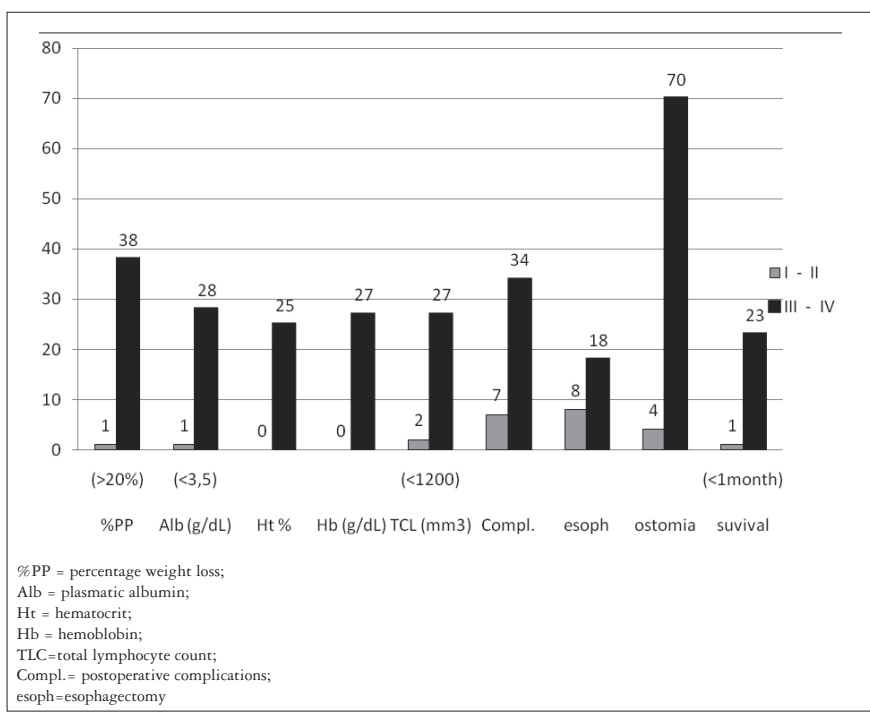

FIGURE 1. Distribution of altered values according to the disease stage (TNM/UICC Classification, 1987)

Mean BMI value was $19.7 \mathrm{~kg} / \mathrm{m}^{2}$, with minor surgery candidates having a mean BMI of $19.3 \mathrm{~kg} / \mathrm{m}^{2}$ and major surgery candidates $20.4 \mathrm{~kg} / \mathrm{m}^{2}$, without significant statistical difference.

Compared to major surgery, minor surgery (ostomy) was characterized by low concentrations of total proteins, albumin, and hemoglobin (males), hematocrit values (males, and total lymphocytes (Table 1). Additionally, CPP was associated with higher weight loss, the wider range of complications (7\%), but not with hypoalbuminemia (Figure 2).

There was no statistical association between percentage weight loss and total or partial esophageal obstruction. However, most patients with partial or total obstruction suffered significant weight loss, more than $10 \%$, in the period before disease diagnosis.

Patient distribution by percentage weight loss according to the degree of surgery is shown in Table 2 . Weight loss over $10 \%$ occurred in $86.5 \%$ of minor surgery candidates and $54 \%$ of major surgery candidates, and the number of early postoperative complications was higher in minor surgery
TABLE 1 . Clinical laboratory values of esophagus cancer patients according to degree of surgery dimension

\begin{tabular}{lccc}
\hline \multirow{2}{*}{ VARIABLES } & \multicolumn{3}{c}{ Surgical groups } \\
\cline { 2 - 4 } & Major $^{*}$ & Minor $^{*}$ & Statistical significance \\
\hline Total proteins (g/dL) & $7.05 \pm 0.64$ & $6.74 \pm 0.72$ & $P=0.070$ \\
Albumin (g/dL) & $3.99 \pm 0.43$ & $3.47 \pm 0.7$ & $P=0.001$ \\
Hematocrit (\%) & & & \\
Masculine & $41.8 \pm 6.39$ & $37.8 \pm 5.4$ & $P=0.005$ \\
Feminine & $41.4 \pm 0.55$ & $37.2 \pm 4.02$ & $P=0.200$ \\
Hemoglobin (g/dL) & & & \\
Masculine & $13.8 \pm 2.0$ & $12.6 \pm 1.94$ & $P=0.019$ \\
Feminine & $13.5 \pm 0.3$ & $13.0 \pm 2.39$ & $P=0.740$ \\
TLC $\left(\mathrm{mm}^{3}\right)$ & $1967 \pm 881$ & $1657 \pm 694$ & $P=0.070$ \\
\hline
\end{tabular}

Student's $t$ test

Major: group submitted to major surgery;

Minor: group submitted to minor surgery

$*$ mean and standard deviation

TLC = total lymphocyte count

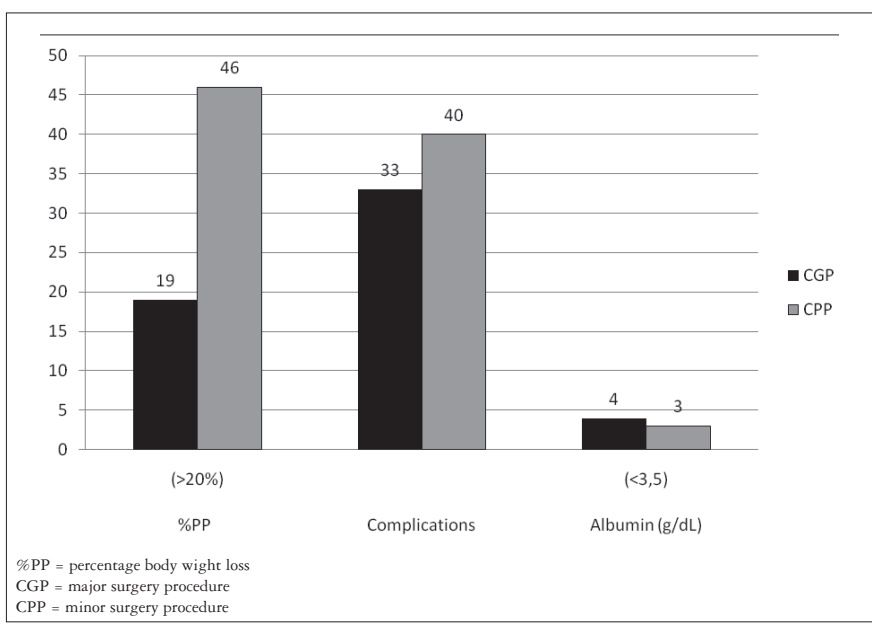

FIGURE 2. Distribution of alterations according to surgery dimension (CGP, CPP)

TABLE 2. Body weight loss and number of complications according to surgery

\begin{tabular}{lcc}
\hline & \multicolumn{2}{c}{ Surgical groups } \\
\cline { 2 - 3 } & Major & Minor \\
\hline$\% \mathrm{PP}$ & & \\
$<10 \%$ & 46 & 13.5 \\
$10-20 \%$ & 35 & 40.5 \\
$>20 \%$ & 19 & 46 \\
Complications* & 33 & 40 \\
\hline
\end{tabular}

Major $=$ major surgery;

Minor $=$ minor surgery

$\% \mathrm{PP}=$ percentage weight loss;

patients (Table 2). Bronchopneumonia was one of the main complications in both types of surgery.

Higher survival is associated with lower weight loss, less postoperative complications, and lower frequency of hypoalbuminemia (Table 3 ). 
TABLE 3. Association between patient survival and body weight loss (\% PP), albuminemia (Alb/g/dL), and presence of postoperative complications

\begin{tabular}{llccc}
\hline & & \multicolumn{3}{c}{ Survival } \\
\cline { 3 - 5 } & & $<$ month & $\geq 1$ month & $\begin{array}{c}\text { Statistical } \\
\text { significance }\end{array}$ \\
\hline \%PP & Serious & 53 & 17 & \\
& Not serious & 3 & 1 & $P=0.052^{*}$ \\
Alb/g/dL & Total & 57 & 18 & \\
& $<3.5$ & 17 & 10 & $P=0.041^{* *}$ \\
& $\geq 3.5$ & 27 & 5 & \\
Complications & Total & 44 & 15 & $P=0.030^{*}$ \\
& Present & 14 & 9 & \\
& Absent & 43 & 9 & \\
& Total & 57 & 18 & \\
\hline
\end{tabular}

Exact Fischer tes

$*$ Chi-squared test

Major surgery patients had higher frequencies of isolated or associated complications compared to minor surgery patients with early postoperative complications $(69.2 \%$ versus $30.7 \% ; P=0.00028$ ).

There was no significant association between plasma albumin, total lymphocyte count, BMI levels and early postoperative complications in patients submitted to major surgery.

To calculate survival by surgical procedure, patients who died in less than 30 days after surgery were excluded in both groups. Mean survival time was 17 months for major surgery, with four patients remaining alive for a median of 10 months. In the minor surgery group, mean survival time was 3.5 months for those who evolved to death, with only 3 of the 75 patients remaining alive until the end of the study.

Surgical mortality was similar in both groups: $23 \%$ in patients submitted to major surgery and $24 \%$ in patients submitted to minor surgery. However, degree of surgery was significantly associated with survival, as major surgery patients had a significantly higher survival rate after the 1st postoperative month.

The relationship between surgical mortality and plasma albumin, total lymphocyte count (TLC), and BMI in major surgery patients showed that survival was predominantly greater than 30 days in patients with TLC $>1200 / \mathrm{mm}^{3}$, however there was no statistical association between death from surgery and plasma albumin in these patients. Weight loss according to the Blackburn et al. ${ }^{(3)}$ classification showed that $90 \%$ of patients studied had serious weight loss, however there was no significant association between weight loss and increased mortality.

Surgical mortality in minor surgery patients was higher in the presence of hypoalbuminemia, with postoperative survival more than 30 days significantly higher in patients with plasma albumin $>3.5 \mathrm{~g} / \mathrm{dL}$ (Table 3 ).

Early postoperative complications and postoperative infections in minor surgery patients were only present in patients with serious weight loss. Surgical mortality was significantly higher in serious weight loss, despite most patients who died up to 30 days after surgery having serious weight loss (Table $3)$. However these patients had a significant association with plasma albumin values (Table 1$)$ and with $\operatorname{TLC}(P=0.036)$.
The kinds of postoperatory complications did not influence significantly the survival of major and minor surgery patients, when analyzed together. However survival was significantly higher in patients who did not have any early postoperative complications (Table 3).

\section{DISCUSSION}

This study included a heterogeneous sample regarding gender, age, and surgical procedure type. The demographic characteristics in these esophagus cancer patients are similar to other national and international studies with a majority of patients being male, white ${ }^{(5,28)}$, and over 60 years old ${ }^{(7,16)}$.

There was a prevalence of Stage III and IV tumors of about $88 \%$, with a higher percentage, around $95 \%$, in the minor surgery group. Oka et al. ${ }^{(20)}$ showed the presence of advanced stage (II \& IV) tumors in $60 \%$ of patients and Gagliardi et al. ${ }^{(14)}$ in $53.4 \%$; these studies did not prioritize patients with removable tumors, as in this investigation. Therefore the percentage of advanced malignant esophagus disease in this study is much higher than in consulted literature and only lower than exclusively palliative studies where all patients had stage III \& IV ${ }^{(11)}$.

The high frequency of smoking and habitual drinking was similar to the other consulted studies. Fonseca et al. ${ }^{(11)}$ found a concomitant presence of alcoholism and smoking in $86.96 \%$ of esophagus cancer patients. Tobacco associated to the consumption of alcoholic beverages significantly increases the development of esophagus cancer ${ }^{(12,13)}$.

Dysphagia was the most frequent symptom similar to other works in literature ${ }^{(10,26)}$.

The high percentage of weight loss, especially in patients submitted to minor surgery, could be due to the picture of starvation linked with local tumor effect; the metabolic stress caused by cytokine and humoral alterations which lead to hypermetabolism with proteic hypercatabolism and anorexia for patients, and consequently depletion of body compartments ${ }^{(19)}$. Also the increased inflammatory activity contributes to the progress of cachexia in patients with advanced malignant disease ${ }^{(17)}$.

Mechanical obstruction of the digestive tube contributes to low protein and energy ingestion favoring weight loss and establishing PEU. In this study, $89 \%$ of patients reported changes in consumed diet consistency; no patient included in the study had pre operative nutrition treatment which could have attenuated food deficit.

The frequency of undernutrition shown in this study is lower than consulted literature ${ }^{(11,27)}$. Esophageal obstruction can be the most evident cause of PEU due to the progressive deficit, until the absence of oral route feeding.

Anorexia is the central component of systemic anorexia/ cachexia syndrome together with local tumor effects. The effects of pro-inflammatory cytokines cause hypercatabolism, mainly in advanced phases of the disease, but mechanical obstruction seems to have a major contribution in the installation of cachexia in esophagus cancer ${ }^{(19)}$. 
Higher survival rate in the major surgery group is expected, as patients submitted to palliative procedures present disease in the advanced stage, complications from the disease, and worse nutritional condition. However, surgical lethality was similar between groups (23\% versus $24 \%)$ and early postoperative complications significantly higher in the major surgery group, despite better nutritional condition measured from anthropometric and biochemical evaluation. This fact could be explained by surgical stress and procedure complexity and their postoperative implications ${ }^{(5)}$.

Surgical mortality in patients submitted to esophagectomy was higher than in literature ${ }^{(5,21)}$. This could be linked to access route used, as $60 \%$ of these patients were operated by transthoracic route.

Ostomies (gastrostomy and jejunostomy) have been used as palliative procedures in esophagus cancer patients since the beginning of the last century, but without manipulating the tumor, as other palliative techniques are effective in reestablishing nutrition for aphagia and dysphagia patients. Literature mentions that surgery has a high morbidity, around $50 \%$, and mortality, with an average survival of 3 months due to surgical complications, especially bronchopneumonia, and terminal state of patients ${ }^{(9)}$.

Early postoperative complications and infections found in patients submitted to gastrostomy and jejunostomy have been significantly linked to plasma albumin values and TLC, and that surgical mortality was higher when plasma albumin depletion was present. Various authors have reported a significant reduction in TLC in patients who present postoperative complications without significant difference in relation to plasma albumin ${ }^{(11,25)}$.

Patients who need palliative treatment due the advanced stage of the disease are often undernourished and present a high risk of complications and operational lethality, having to carefully look at the risks and benefits of the indicated treatment, as well as the level of nutritional compromise and possibilities of nutritional intervention. Modern palliative nutritional treatment has the aim and task to improve patient quality of life and prolong survival, which count on different intervention methods which must also interact with organic functions, and hormonal and inflammatory response ${ }^{(17,23,26)}$.

This study confirms the importance of early diagnosis and treatment of the disease in the sense of impeding or retarding its worsening to preserve patient nutritional state, permit surgical intervention and radiotherapy treatments, with less postoperative morbidity and consequently better patient survival. This is because treating patients in the advanced stage of the disease finds them already undernourished with only possibilities of palliative surgery which does not protect from postoperative complications or higher mortality.

In both cases pre and postsurgical nutritional treatment deserve importance, in the first case by oral route, and in the second by parenteral-enteral route. However, the most appropriate would be early diagnosis, allowing nutritional intervention support to surgical-radiotherapeutic interventions.

The major limitations of the present data are the absence of a non-surgical control group and the lack of information regarding their postsurgery nutritional interventions.

\section{CONCLUSION}

The results found in this investigation permit the conclusion that once again disease severity causes worse nutritional state which complicates postsurgery and is associated with mortality, recommending early diagnosis and nutritional treatment to support surgical action.

Marin FA, Lamônica-Garcia VC, Henry MACA, Burini RC. Impacto do estágio do câncer de esôfago e do estado nutricional sobre os desfechos pósoperatórios. Arq Gastroenterol. 2010;47(4):348-53.

RESUMO - Contexto - A desnutrição protéico-energética constitui causa previsível para o desenvolvimento de complicações pós-operatórias e pior prognóstico de pacientes cirúrgicos. Objetivo - Estudar a associação de indicadores de estado nutricional com estádio da doença e as principais complicações e mortalidade pós-operatória de pacientes com câncer de esôfago. Método - Foram avaliados retrospectivamente 100 prontuários de pacientes com câncer de esôfago (38-81 anos) de ambos os sexos ( $85 \%$ masculino e $15 \%$ feminino) submetidos a esofagectomia $(n=25)$ e gastrojejunostomia $(n=$ 75), no período de 1995 a 2004. Os dados coletados foram: história clínica, exame endoscópico, estádio (TNM-UICC), estado nutricional (índice de massa corporal, percentual de perda de peso - \%PP, albuminemia e contagem de linfócitos total) e evolução clínica pós-operatória. Houve composição dos grupos de acordo com o porte da cirurgia (grande x pequeno). Foi realizada a associação entre as complicações pós-operatórias e a mortalidade (após pós-operatório de 30 dias). As comparações entre médias dos dois grupos foram feitas pelo teste $t$ de Student e a existência de associações entre variáveis testadas pelos testes de $\chi^{2}$ ou exato de Fisher com $P=0,05$. Resultados - Houve predomínio dos tumores avançados (estádio III e IV), com a presença de disfagia em $95 \%$ dos pacientes e perda ponderal $>10 \%$, anterior ao diagnóstico, em $78 \%$. A obstrução esofágica, presente em 77 pacientes, foi associada $(P=0,0021)$ com o baixo índice de massa corporal (desnutrição protéico-energética). A \%PP e a hipoalbuminemia associaram-se estatisticamente $(P<0,05)$ com o estádio avançado da doença. As complicações pós-operatórias precoces ocorreram em $69,2 \%$ e 30,7\% dos pacientes submetidos a esofagectomia e ostomias, respectivamente, com predomínio das infecciosas nas ostomias $(80 \%)$ e as pleuropulmonares nas esofagectomias (61\%). A albuminemia foi menor nos pacientes submetidos as ostomias, tendo sido a hipoalbuminemia associada $(P<0,05)$ com a ocorrência de complicações pós-operatórias e mortalidade. A \%PP e a contagem de linfócitos total associaram-se com as complicações pós-operatórias precoces e infeccionas nas ostomias e a contagem de linfócitos total, com a mortalidade operatória nas esofagectomias. Conclusões - O estado de DPE esteve associado às complicações pós-operatórias apenas nos pacientes submetidos a ostomias, sem presença destas associações nas esofagectomias.

DESCRITORES - Neoplasias esofágicas. Estadiamento de neoplasias. Estado nutricional. Complicações pós-operatórias. Evolução fatal. 


\section{REFERENCES}

1. Aiko S, Yoshizumi Y, Ishizuka T, Horio T, Sakano T, Kumano I, Kani M, Maehara T. Enteral immuno-enhanced diets with arginine are safe and beneficial for patients early after esophageal cancer surgery. Dis Esophagus. 2008;21:619-27.

2. Baxter YC, Dias MC, Maculevicius J, Cecconello I, Cotteleng B, Waitzberg DL. Economic study in surgical patients of a new model of nutrition therapy integrating hospital and home $v s$ the conventional hospital model. JPEN J Parenter Enter Nutr. 2005;29 (Suppl 1):s96-s105.

3. Blackburn GL, Bistrian BR, Maini BS, Schlamn HT, Smith MF. Nutritional and metabolic assessment of the hospitalized patient. JPEN J Parenter Enteral Nutr. 1977;1:11-32.

4. Bozzetti F, Cozzaglio L, Gavazzi C, Bidoli P, Bonfanti G, Montalto F, Soto Parra H, Valente M, Zucali R. Nutritional support in patients with cancer of the esophagus: impact on nutritional status, patient compliance to therapy, and survival. Tumori. 1998;84:681-6.

5. Cariatti A, Casano A, Campagna A, Cariati E, Pescio G. Prognostic factors influencing morbidity and mortality in esophageal carcinoma. Rev Hosp Clin Fac Med São Paulo. 2002;57:201-4.

6. Chandra RK, Kumari S. Nutrition and immunity: an overview. J Nutr. 1994;124:s1433-s5.

7. Chau I, Norman AR, Cunningham D, Waters JS, Oates J, Ross PJ. Multivariate prognostic factor analysis in locally advanced and metastatic esophago-gastric center - pooled analysis from three multicenter, randomized, controlled trials using individual patient data. J Clin Oncol. 2004;22:2395-403.

8. Correia MI, Waitzberg DL. The impact of malnutrition on morbidity, mortality, length of hospital stay and coast evaluated through a multivariate model analysis. Clin Nutr. 2003;22:235-9.

9. Domene CE, Cecconello I, Zilberstein B, Ishioka S, Sakai P, Pinotti HW. Tunelização esofágica na fístula esofagotraqueobrônquica. Rev Col Bras Cir. 1999;26:91-5.

10. Finley JP. Management of cancer cachexia. AACN Clin Issues. 2000;11:590-603.

11. Fonseca CAM, Sobrinho JA, Pesciotto A, Rapoport A. O tubo gástrico isoperistáltico no tratamento paliativo do câncer do esôfago. Rev Col Bras Cir. 2002;29:202-8

12. Franceschi S, Talamini R, Barra S, Barón AE, Negri E, Bidoli E, Serraino D, La Vecchia C. Smoking and drinking in relation to cancers of the oral cavity, pharynx, larynx and esophagus in northern Italy. Cancer Res. 1990;50:6502-7.

13. Freitas MC, Moretzsohn LD, Coelho LG. Prevalence of Barrett's esophagus in individuals without typical symptoms of gastroesophageal reflux disease. Arq Gastroenterol. 2008;45:46-9.

14. Gagliardi D, Corsi PR, Frimn CE, Fava J. Câncer do esôfago - complicações pós-operatórias imediatas e letalidade hospitalar. Rev Col Bras Cir. 2004;31:2-9.

15. Galvão MSL, Pinto CE, Sbalchiero JC. O uso do tubo colônico bipediculado microcirúrgico na reconstrução do esôfago. Rev Col Bras Cir. 2003;30:238-40.

16. Loureiro JFM, Ilias EJ, Curiati PAL, Kassab P, Safatle NF. Análise retrospectiva de 43 pacientes com câncer de esôfago atendidos no Hospital Geral do Grajaú da Faculdade de Medicina de Santo Amaro [resumo]. Rev Col Bras Cir. 2005;32 (suppl):139.
17. Lundholm K, Daneryd P, Bosaeus I, Körner U, Lindholm E. Palliative nutritional intervention in addition to cyclooxygenase and erythropoietin treatment for patients with malignant disease: effects on survival metabolism and function. Cancer. 2004;100:1967-77.

18. Malafaia O. Experiência de 15 anos com o tratamento paliativo do câncer do esôfago através da tunelização esofágica. Rev Col Bras Cir. 1986;13:211-5.

19. Mantovani G, Macciò A, Massa E, Madeddu C. Managing cancer-related anorexia/cachexia. Drugs. 2001;61:499-514.

20. Oka M, Yamamoto K, Takahashi M, Hakozaki M, Abe T, Iizuka N, Hazama S, Hirazawa K, Hayashi H, Tangoku A, Hirose K, Ishihara T, Suzuki T. Relationship between serum levels of interleukin 6, various disease parameters, and malnutrition in patients with esophageal squamous cell carcinoma. Cancer Res. 1996;56:277-80.

21. Pinto EC, Dias JA, Sá EAM, Carvalho ALL. Esofagectomia de resgate após quimiorradioterapia radical exclusiva: resultados do Departamento de Cirurgia Abdominopélvica do Instituto Nacional de Câncer. Rev Col Bras Cir. 2007;34:1620 .

22. Saito T, Kuwahara A, Shigemitsu Y, Kinoshita T, Shimoda K, Miyahara M, Kobayashi M, Shimaoka A. Factors related to malnutrition in patients with esophageal cancer. Nutrition. 1991;7:117-21.

23. Sakurai Y, Masui T, Yoshida I, Tonomura S, Shoji M, Nakamura Y, Isogaki J, Uyama I, Komori Y, Ochiai M. Randomized clinical trial of the effects of perioperative use of immune-enhancing enteral formula on metabolic and immunological status in patients undergoing esophagectomy. World J Surg. 2007;31:2150-7.

24. Scrinshaw NS, Guzmán MA, Flores M, Gordon JE. Nutrition and infection field study in Guatemalan villages, 1959-64. V. Disease incidence among preschool children under natural village conditions, with improved diet and medical and public health services. Arch Environ Health. 1968;16:223-4.

25. Strutyńska-Karpińska M, Markocka-Maczka K, Grabowski K, Nienartowicz M Alashi A. Multifactorial analysis of respiratory complications in patients after subtotal esophagectomy because of cancer. Adv Clin Exp Med. 2006;15:817-26.

26. Takeuchi H, Ikeuchi S, Kawaguchi Y, Kitagawa Y, Isobe Y, Kubochi K, Kitajima M, Matsumoto S. Clinical significance of perioperative immunonutrition for patients with esophageal cancer. World J Surg. 2007;31:2160-7.

27. Tomasich FDS, Valladares GCG, Demarchi VCA, Gagliardi D. Complicações e letalidade hospitalar da esofagectomia com linfadenectomia em dois campos: estudo de 132 casos. Acta Oncol Bras. 2003;23:375-87.

28. Valladares GG, Tomasich FDS, Targa GZ, Gaverrete DD, Dias LAN. Câncer de esôfago. Estudo de 1292 casos tratados no período de 1990 a 2003 [resumo]. Rev Col Bras Cir. 2005;32(Supl):139.

29. Waitzberg DL. Avaliação nutricional: exames laboratoriais. In: Waitzberg DL, editor. Nutrição oral, enteral e parenteral na prática clínica. São Paulo: Atheneu; 2000. p.279-94.

30. World Health Organization - WHO. Physical status: the use and interpretation of anthropometry. Geneva: WHO; 1995. (WHO technical report series 854).

31. World Health Organization - WHO. Obesity: preventing and managing the global epidemic. Geneva: WHO; 2000. (WHO technical report series 894).

Received 25/6/2009. Accepted 18/3/2010 